\title{
Practice and Exploration of Undergraduate Training Program for Innovation and Entrepreneurship in Independent Colleges
}

\author{
Feng WANG ${ }^{1, a,{ }^{*}, \text { Liang DAI }}{ }^{2, b}$, Wei-chuan $\mathrm{NI}^{3, c}$ \\ and Shao-jiang LIU ${ }^{4, d}$ \\ ${ }^{1,2,3,4}$ Xinhua College of Sun Yat-sen University, Guangzhou 510520, China \\ a78133090@qq.com, b66974630@qq.com, '544737200@qq.com, \\ 690484520@qq.com
}

Keywords: Undergraduate Training Program for Innovation and Entrepreneurship, Independent College, Innovation and Entrepreneurship Education.

\begin{abstract}
As a university priority project, undergraduate training program for innovation and entrepreneurship has been implemented for many years, it is a kind of innovation and entrepreneurship practice project for college students, and promote the development of various types of innovation and entrepreneurship education and related academic competitions in colleges and universities, promote the development of the reform of higher education. In this paper, we mainly discuss how to implement the undergraduate training program for innovation and entrepreneurship, how to establish the management system, the operation mechanism, the implementation methods and so on. Continue to explore the project's scientific management, incentive system, characteristic construction, a guiding mechanism, tutorial system, innovation and entrepreneurship education reform and so on. Gradually through the training program to enhance the overall quality of students and improve their practical ability, the formation of a long-term mechanism to promote and the formation of the school characteristics.
\end{abstract}

\section{Introduction}

The national long-term education reform and development plan (2010 - 2020) clearly states: improve the quality of personnel training, strive to cultivate faith perseverance, good moral character, knowledge, skills, excellent high-quality talent, and top-notch innovative talents and strengthen employment and entrepreneurship education[1]. Undergraduate training program for innovation and entrepreneurship is initially focused on university students science and technology practice projects, in 2011 and 2012, respectively issued "Opinions of the Ministry of Finance on implementing the project of teaching quality and teaching reform in colleges and universities during the 12th Five Year Plan Period" and "Notice of the Ministry of Education on approving and implementing the construction project of 2012 "undergraduate teaching quality and teaching reform project of higher education", the Ministry of Education decided to implement the national undergraduate training program for innovation and entrepreneurship in the "12th Five-Year" period. In 2013, independent colleges began to declare national projects, establish the University - Provincial - National three levels of the system. In 2014, the 7th National Undergraduates' Innovation and Entrepreneurship Conference was held, which is an important part of the university's innovation and entrepreneurship system as well as the key construction contents of the undergraduate teaching quality project. All levels of undergraduate training program for innovation and entrepreneurship are divided into three categories, innovative training 
projects, training programs for entrepreneurship and entrepreneurial practice projects, schools have established a management system, the school students each year to declare, in accordance with the requirements of inspection and conclusion, the formation of a daily work within a school.

\section{The Management System of Undergraduate Training Program for Innovation and Entrepreneurship in Our School}

Undergraduate training program for innovation and entrepreneurship is part of the undergraduate teaching quality project. Therefore, it belongs to the management system of the quality engineering of the Ministry of Education, adopts the management of personnel, sets up the practical management system, supporting measures and management methods, and coordinates the management departments. As the annual normal work issued the notice in April, each department organization report to work. In addition, the Ministry of Education preach the work of training program in 2 campuses to promote the purpose of the whole school students to understand and familiar with the undergraduate training program for innovation and entrepreneurship, the department also actively mobilize teachers and students to declare. The specific responsibility of the Ministry of Education is responsible for the management of the school document development, mobilization, and organization, and collect and summarize the projects from each department, and ask experts to review the project, merit admission, strict quality control.

The department first screening out high-quality projects, and then let the experienced teacher as an instructor, control the number of teachers to ensure the quality of the completion, and then unified time to declare up, the Ministry of Education makes a summary of the project. Arrange the comprehensive assessment of the professional experts, according to the selection of high quality and outstanding projects, feedback on project views, according to the views of the Ministry of Education feedback to the Department, the approved project also need to modify the views of experts to submission. And then the school publicity, the use of scientific management methods, each year after the release of the project for the new year, the release of the project in the previous year to check and solve problems, students who have completed or are about to graduate will be allowed to complete the project in advance, and the management method can be flexibly changed according to the actual situation. The project manager who has been declared through can join the training program management group, in which can put forward their own questions and advice, on the one hand, the whole process of monitoring the progress of student projects, on the other hand, the department also arranged teachers for unified management, mainly to play a supervisory role, can be completed in accordance with the requirements of the project.

All teachers are actively involved in guiding undergraduate training program for innovation and entrepreneurship, the conversion of the teacher's workload according to the level of the project is an affirmation of the teacher's work. In addition, set up innovative credits for students, through the completion of the project and published high-quality papers, students can apply to get credits. Students can put their spare time and vacation time into practice, in particular, to improve the student's enthusiasm and assiduously spirit. Each year the application of the project and ongoing projects, including those finished projects, have formed a good heritage, the strength has increased year by year, the number and quality to a higher level, senior students have a 
subtle influence on the junior students, and the schools paying increasing attention to the projects.

\section{Further Exploring the Construction of Undergraduate Training Program for Innovation and Entrepreneurship}

With the development of the school disciplines and majors, to incorporate the undergraduate training program for innovation and entrepreneurship into the teaching management system, it is necessary to integrate the project into the management of practice teaching and assign the person to manage by the Ministry of Education department. In order to better serve the students and teachers, while the teacher's work is also included in the assessment system. It is necessary to establish a complete management system and evaluation system from top to bottom, attach importance to the management of the project and play the role of the project in teaching, and further improve the overall quality of students, so that students can use the knowledge they have learned in the university and even cross-disciplinary knowledge to complete the specific projects independently, to lay a good foundation for further study or work.

To further enhance the use of service attitude in communicating with students and teachers, looking for the sake of students and teachers to realize the implementation of communication channels flat [2]. In the process of management, the educational department takes centralized management in a flat way, emphasizes the process management, concentrates on the teachers' service in the three stages of the beginning, middle and end of the semester, check and supervise the progress of the project. The completion of the project as a part of teaching inspection, so that we can grasp the implementation and progress of the project, convenient to solve problems, rather than the emergence of a variety of conditions at the end of the project. Teachers through the examination to complete their task, guide the students to complete the project according to the project schedule, can communicate in a timely manner, in order to avoid teaching task and ignore the progress of student projects. The implementation and completion of the project are related to the practical ability of the students' learning process and help the students to solve the problems in order to complete the project. The educational departments should also start the survey when concluding each project, found problems in a timely manner to improve management practices, combined with the actual situation to take measures for the management of refinement process, make the quantity and quality of student projects strive for further improvement. In the process of construction, we should listen to the feedback from teachers and students, and deal with the unexpected situation.

Formulate a series of management measures. In 2012, the "Management Method of Student Innovation and Entrepreneurship Training Program of Xinhua College of Sun Yat-sen University" (Trial) was introduced from the aspects of organization and management, project declaration and evaluation, project management, fund management, selection and management of instructors, recognition and reward, in three aspects, from the management organization to reward the incentive policy. At the student level, it is possible to identify innovative practice credits for students who have completed the project and have achieved results, the school provides 3 innovative credits, and students can also further improve the project as their graduation thesis (Design), praise and reward the best students. At the teacher level, according to the level of the guidance of the project and the completion of the grant of teaching workload, and as a basis for teachers' assessment. At the school level, set up three stages of the 
working group from the school to the campus to the department, manage and monitor the implementation of the project, and ensure the smooth implementation of the project.

In the implementation process, the education department will mobilize the project at the beginning of the new school year, to take the form of lectures for students, the organization is responsible for the teachers. In the form of the curriculum by experienced teachers to organize students to write the proposal, strict requirements of the content and format of the project, the completion of the proposal are inseparable from the guidance of teachers, and finally unified submitted to the educational department. Relying on the school committee of experts, the development of three aspects of the assessment rules, namely the project evaluation, interim inspection and knot acceptance, to ensure fair and impartial assessment of the project[3]. In the process of the project, rational use of budget funds and be reimbursed for one's actual expenses, the educational department staff unified reimbursement arrangements, solve students the use of funds. At the end of the completion of the project will be arranged and making the relevant certificates, complete the project according to the whole process each year.

\section{The Guidance of the Instructor System for Undergraduate Training Program for Innovation and Entrepreneurship}

The instructor of the undergraduate training program for innovation and entrepreneurship can be either one or two, the role of teachers is as students practice innovation and entrepreneurship instructor. In general, before the student's declaration, students can have the idea and then find a professional teacher to discuss, teachers can also be related to the recommendations of the students or other ways, but ultimately teachers need to conduct checks. Students lack of experience in thinking ability and project prediction, even if there are good ideas may also fail. The role of the instructor is not only to improve the student's project but also to check the quality of student projects, to guide students to develop practical solutions before they can better complete the project application.

Generally in accordance with the requirements, as a project instructor, the first must be a graduate degree or above. Basically, every year, the first instructor of the project are all intermediate title or above, The lack of professional title and academic qualifications of teachers generally as a second instructor, the instructor's academic level is also more important. Student's project level is not only based on the content, but also by their instructors. In particular, provincial and national projects need to encourage more experienced teachers in charge, after all, in the academic research, experienced teachers with high professional titles have advantages, can achieve better results. It is only the first step to guide the students to apply for the project, and the initial stage of the project, so in terms of expectations should be based on the actual situation. The project application is mainly by sophomore and junior students because freshman students lack professional knowledge and academic literacy, and senior students facing graduation and other issues. Students can come from different professions, teachers can also be a free combination, to encourage interdisciplinary reporting, so as to expand the horizons of students and instructors.

Many teachers only pay attention to the declaration, do not attach importance to the guidance and management of students, lead to the project quality decreased, so the instructor is the key to the project [4]. Mentioned earlier, the guidance of the project should be included in the teaching management, but also as an instructor personal 
performance assessment. The completion of the project and the improvement of quality are also related to the development of the undergraduate training program for innovation and entrepreneurship; therefore, the instructor's supervision and management is particularly important. In the process management, by the Ministry of Education to assist the mentor to carry out joint projects and management, especially when students encounter problems, the teacher should actively help and solve it. On the basis of the completion of the project accounting teacher workload, reward the completed projects. In the aspect of performance evaluation, through a series of measures to improve the students' comprehensive academic level and professional level of teachers.

\section{Project Integration into Innovative and Practical Teaching}

In the independent college teaching reform, has always stressed that the practice of teaching, an undergraduate training program for innovation and entrepreneurship is actually the practical project for college students. To integrate it into the teaching practice, we can better stimulate students' enthusiasm for the project. In addition, the practice of teaching can also be the formation of various types of teaching projects, as the prototype of the declares project, and promote experimental teaching by project and improve the quality of experimental teaching [5]. The implementation process of the project is a process of mutual discussion, similar to the way of practice teaching, in the form of a group to complete a work, so that the content of practice teaching can be organically combined, students can also understand its principle. Generally, the practice teaching is verified, and the comprehensive and design are relatively less if it is a complete project, so the students can use knowledge independently, even the knowledge has not learned, this process also belongs to the practice teaching method.

Students can make full use of the laboratory teaching center to complete their basic experiments and comprehensive experiments. Based on that, students find the relevant literature; produce an idea, with the help of practical courses to complete the design of their own projects. Through the whole process in the practice teaching, students project can even introduce into the content of practical courses, so that we can better service teaching, and teachers can also complete the task of teaching practice while guiding the students' projects, put the experiment and project together, to mutual penetration, to mutual coordination, so as to improve the quality of training.

\section{Conclusion}

Students in the scientific research experience, not only access to intellectual development but also gain professional socialization, that is, to recognize and experience the quality and attitude of the research [6]. The aim of an undergraduate training program for innovation and entrepreneurship is to improve students' ability of innovation and entrepreneurship, in the implementation process to constantly improve their own knowledge system and learn to communicate and set up the team. In the management process, students can learn to solve various problems, deepen the integration of professional knowledge and different disciplines, in particular, to strengthen the understanding of theoretical knowledge, will no longer think that the theoretical knowledge of the book completely useless, but will think it is very important. At the same time, the practice teaching has been strengthened; the school should vigorously promote the innovation and entrepreneurship training program coverage, 
can play a better leading role and integrated into the daily teaching system, and further, promote the improvement of teaching quality.

\section{Acknowledgement}

This research was supported by the Undergraduate Higher Education Reform Project of Guangdong Province 2016: Feng WANG, Zhi-ping WAN, Jing LI, Ze-min QIU, Wei-chuan Ni, Shao-jiang LIU, Liang-yu LI. Research and Exploration on Innovative Education System for Undergraduates to Promote Innovation Education Credits -Based on Undergraduate Training Program for Innovation and Entrepreneurship. Starting at September 2016 and ending at July 2018. Date of approval: November 12, 2016.

\section{References}

[1] Outline of the national medium and long-term education reform and development plan of the Central People's Government of People's Republic of China [EB/OL]. (2010-07-29). http://www.gov.cn/jrzg/2010-07/29/content_1667143.htm.

[2] Jian-wen ZHANG, Cheng ZHANG, Xiao-ming CHANG, Rui ZHANG, Yong-qiang CHENG. Exploration and Practice of the Effectiveness of Process Management in Local College Students' Innovative Training Program [J]. Research in Higher Education of Engineering, pp. 135-138, May 2014.

[3] Chang-hong LIU, Xiao-hui LI, Gang LI, Qing-rong YUE, Yong-gong REN. Practice and Exploration of the Undergraduate Innovation and Entrepreneurship Training Program[J]. Research and Exploration in Laboratory, vol. 33, pp. 163-166, May 2014.

[4] Xiao-ming QIAN, Hua-wei RONG, Jing-zhu QIAN. Practice and thinking of education of "College Students' Innocative and Entrepreneurial Training Program" based on tutor system [J]. Experimental Technology and Management, vol. 31, pp. 21-24, July 2014.

[5] Yan-fang Zou, Li-xin ZHANG, Ming GAO, Zhi-yun WANG. Synergic relationship between "Undergraduate Innovation and Entrepreneurship Training Program" and experimental teaching [J]. Experimental Technology and Management, vol. 33, pp. 172-185, September 2016.

[6] Hui GUO, Ting HAN, Xiu-ping YU, Hui-juan NIU, Zhi-qi TIAN. Study on the Benefits of Research Experiences for Undergraduates of Science and Technology: Based on the Investigation of "National College Students Innovation and Entrepreneurship Training Plan' $[\mathrm{J}]$. Research in Higher Education of Engineering, pp. 59-66, June 2015. 